non-governmental aid organizations and African governments alike.

Without support for post-primary mathematics and science education, Africa will remain dependent on foreign experts to craft policy, meet the needs of industry, perform research, combat disease and run the economy. Africa needs African experts, for the local knowledge they bring - particularly in fields such as epidemiology - but also because true independence will be achieved only when such skills can be found domestically.

In a report to a $2009 \mathrm{UN}$ conference in Addis Ababa on strengthening sciences in Africa, Aderemi Kuku, a US-based Nigerian mathematician and founder of the Mathematicians of the African Diaspora network, said that the continent has no critical mass in a single field of mathematics. He warned: "When the present generation of University teachers and researchers in Mathematics and Physics, disappear from the scene due to retirement etc., the situation will be near disaster unless urgent steps are taken."

As we report on page 176, Neil Turok, a South African cosmologist and head of the Perimeter Institute for Theoretical Physics in Waterloo, Canada, has led efforts to combat this trend. Turok pioneered the construction of the African Institute for Mathematical Sciences (AIMS), a hothouse of post-secondary mathematics teaching and research in Muizenberg, South Africa. The model has now been adopted in Ghana and Senegal, too. Turok hopes for a total of 15 institutes across the continent. He laments what he calls a science faculty "generation gap" and is critical of the way that international

donors tend to emphasize basic education.

"Nobody's been interested," he told Nature. "The West for many years has been happy to deal with Africa on a charity basis, but investing in skills in people was not a priority. This was a major error."

Bravo to AIMS for responding to the crisis of maths and science education on the continent, but, as Turok and his colleagues will be the first to say, the efforts remain modest given the scale of what is needed.

"Science needs Africa as much as Africa needs science."

other projects. In the space of ten years, AIMS has built a network of successful mathematics institutes for a few tens of millions of dollars.

And think of the payback. Science needs Africa as much as Africa needs science. What a waste of human talent not to have Africa participate as a scientific peer, for a world content to wait for Africa's entry into science. What advances has humanity missed out on by having the continent so cut off from the mainstream of scientific debate and discovery?

The late evolutionary biologist Stephen Jay Gould once said: "I am, somehow, less interested in the weight and convolutions of Einstein's brain than in the near certainty that people of equal talent have lived and died in cotton fields and sweatshops." Africa has that talent. Some of it may be discovered at AIMS. But much of it will not be.

\section{John Maddox prize}

Two strong-minded individuals are the first winners of an award for standing up for science.

\section{$\mathrm{T}$} he British psychiatrist Simon Wessely and the Chinese science writer Shi-min Fang are the two inaugural winners of the John Maddox Prize. Sponsored by Nature and the Kohn Foundation, and stimulated and organized by the UK-based charity Sense About Science, the prize commemorates a former Editor of Nature, John Maddox. John was distinguished for his championing of robust science. The prize rewards individuals who have promoted sound science and evidence on a matter of public interest, with an emphasis on those who have faced difficulty or opposition in doing so. In this inaugural year, the judges (see go.nature.com/9rvd1t) were able to make two awards, each of $£ 2,000$ (US\$3,200).

China's rush to modernize and the communist government's celebration of science and technology have firmly embraced scientists and scientific achievements, sometimes uncritically. And into that permissive milieu has walked a plethora of opportunists ready to take advantage of the situation with padded CVs, fraudulent and plagiarized articles, bogus medicines and medical procedures carried out without clinical evidence.

In 2000, Shi-min Fang started to expose these escapades in his New Threads website. As an outsider, trained as a biochemist but turned science writer and commentator, he has done much of what the scientific community aims, but often fails, to do - root out the fakers.

For example, Fang called into question DNA supplements that were widely advertised as a means to rejuvenate the tired, the pregnant and the old. Eventually, the government issued warnings about the supplements. Fang seemed to especially relish smacking down powerful or popular scientists. He even challenged official support of traditional Chinese medicine. But his targets fought back, in one case with particular hostility. In the summer of 2010, thugs hired by a urologist attacked Fang with a hammer and, according to Fang, tried to kill him. Fang had previously challenged not only the efficacy of a surgical procedure developed by the urologist, but also his CV.

Fang imposes transparency on an opaque system. He has opened a forum for criticism and debate in a community that is otherwise devoid of it.

Simon Wessely is a psychiatrist at the Institute of Psychiatry, King's College London, who has specialized in two areas above all - the mental health of military personnel and veterans, and chronic fatigue syndrome. He and his colleagues demonstrated substantial overlap in symptoms between chronic fatigue syndrome and clinical depression. He carried out a massive and ambitious study to test the link between common viral infections and later fatigue, and found that there is no simple causal association. He subsequently developed a treatment approach using cognitive-behavioural therapy techniques, which in many cases brought about substantial improvement and in some was life transforming. This treatment was tested in large clinical trials and can now be found in the guidelines of the United Kingdom's National Institute for Health and Clinical Excellence.

"All along the way," says the individual who nominated him for the prize, "Wessely has had to suffer continued abuse and obstruction from a powerful minority of people who, under the guise of self-help organizations, have sought to promote an extreme and narrow version of the disorder. This version repudiates any psychological or psychiatric element to the extent that psychiatry is viewed as a contemptible discipline, which, by association, denigrates psychiatric patients. Hostile letters, e-mails and even death threats have been directed at Professor Wessely over two decades. Mischievous complaints have been made against him and his clinical team, and bogus questions raised in the Houses of Parliament. He has suffered a vigorous Internet assault and coordinated attempts have been made to turn him into a hate figure. He has been compared to Josef Mengele - particularly hurtful since Simon is the son of holocaust survivors. Simon has, perhaps naively, tried to deal with most of these by seeking dialogue and trying to educate and reassure, rather than by responding in kind."

Wessely is the first to acknowledge that others working in this field have received similar or even worse abuse. $\rightarrow$ NATURE.COM To comment online, click on Editorials at: go.nature.com/xhunqv Nevertheless, the prize recognizes the very public stand that Wessely has taken over these issues.

Nature congratulates Simon Wessely and Shi-min Fang on their awards. 